Part of Journal of Research of the National Bureau of Standards, Volume 22, June 1939

\title{
RESOLVING POWER AND DISTORTION OF TYPICAL AIRPLANE-CAMERA LENSES
}

\author{
By Francis E. Washer
}

\section{ABSTRACT}

Tabulations are given of the resolving power and distortion of a number of airplane-camera lenses of the type most commonly used in recent air-mapping projects. Since the image plane of best average definition does not necessarily coincide with the image plane yielding best definition on the axis of the lens, the method of selecting the image plane of best average definition and its use in connection with the determination of the equivalent focal length are described. The manner of the variation of the resolving power across the field is characteristic of the type of lens.

\section{CONTENTS}

II. Method of selection of the image plane of best average definition

III. Resolving powers for typical airplane-camera lenses_........... 733

IV. Distortion for typical airplane-camera lenses.

V. Conclusion_... 746

\section{INTRODUCTION}

In 1927 a paper by A. H. Bennett ${ }^{1}$ listed the distortion characteristics of some typical photographic objectives. In the intervening 12 years the growth of air-mapping operations has been rapid. This growth, together with the desire to obtain negatives satisfactorily free from distortion and including as great an area of the terrain as possible, has resulted in the construction of wide-angle photographic objectives of short focal length with distortion lower than that of lenses built 15 or 20 years ago. In order to combine the advantages of a convenient negative size and a wide angular field, the focal length of lenses employed in airplane-mapping cameras seldom exceeds $210 \mathrm{~mm}$.

For several years it has been a requirement that all lenses used on Government mapping projects be tested by the National Bureau of Standards. This requirement, and the natural demand of the map makers for greater accuracy in their negatives, has resulted in the submission of a very large number of lenses to the National Bureau of Standards for determination of focal length, distortion, and resolving power. To facilitate these measurements, a precise lens-testing camera has been developed. On the basis of these measurements, this paper presents a survey of the distortion and resolving-power characteristics of a number of airplane-camera lenses. Such a critical comparison and study of the data resulting from so large a 
number of standardized tests are most useful, because they present definite quantitative data that can be used in the preparation of performance specifications for airplane-camera lenses and for making an estimate of the accuracy possible for a given mapping process.

Only the lenses most commonly used in recent air-mapping projects are studied, thus limiting this survey to lenses of $210-\mathrm{mm}$ focal length and apertures of $f / 4$ and $f / 6.8$. The lenses are considered in three groups corresponding to the product of three manufacturers, two domestic and one foreign. This study has been limited to the products of three manufacturers, because sufficient recent data on other makes of $210-\mathrm{mm}$ lenses are not available. The three types herein considered comprise more than 80 percent of the total number of $210-\mathrm{mm}$ lenses tested at the National Bureau of Standards in the past 2 years.

\section{METHOD OF SELECTION OF THE IMAGE PLANE OF BEST AVERAGE DEFINITION}

The lens-testing camera to which reference has been made, the operating technique, and the method of deriving equivalent focal length (E. F. L.) and distortion from the test negative have been described in an article ${ }^{2}$ by Gardner and Case. However, to insure clarity in this report, a brief survey of this equipment and procedure is given

The lens-testing camera consists of seven collimators spaced at approximately $5^{\circ}$ intervals, a lens holder, and a plateholder. The collimators serve to produce parallel light, so that a lens may be tested under conditions closely approximating those encountered in aerial photography. The angle between each pair of adjacent collimators is measured to five significant figures, with a probable error not in excess of $\pm 0.0010^{\circ}$, and no systematic error in excess thereof has been found. Each collimator carries a test chart so designed and mounted that the images on the test negative for a distortion-free lens will all be equal in size regardless of their angular separation from the axis of the lens. Each target contains a central vertical line which serves as a fiducial mark for the measurements made, in order to determine the equivalent focal length and distortion of a lens. The lens under test is placed at the intersection point of the seven collimator axes, and is so adjusted that the axis of the first collimator coincides with that of the lens. Hence, the other six collimators make angles with the axis of the lens of approximately $5^{\circ}, 10^{\circ}, 15^{\circ}, 20^{\circ}, 25^{\circ}$, and $30^{\circ}$, respectively. The plateholder is so constructed that it may be moved along the axis of the bench in equally spaced steps. The plateholder may also be moved in a plane at right angles to the plane of the collimators, so that 19 rows of images may be taken on a single plate where each row shows the imagery in focal planes at successively increasing distances from the lens. The range of movement of the plateholder along the axis is so selected that the middle row of images corresponds to the best visual focus. After the test negative has been produced, a row is selected on the basis of best average photographic definition across the entire field. For this row, measurements are then made of the distances separating the central or fiducial line of each image from that of the axial image. The measured values of these distances are used for the determination

\footnotetext{
2 J. Research NBS 18, 449 (1937) RP984.
} 
of equivalent focal length and distortion. Let $a$ be the distance from the $0^{\circ}$ to the $5^{\circ}$ image and $b$ the distance from the $0^{\circ}$ to the $10^{\circ}$ image, then $f=\left(f_{1}+f_{2}\right) \div 2$, where $f_{1}=a$ cot $5^{\circ}$ and $f_{2}=b \cot 10^{\circ}$. The measured distances from the axial image to the images at the other $5^{\circ}$ intervals are used in computing the distortion of the lens.

A consideration of the resolving power of the lens in different image planes is the basis for the selection on the test negative of the row that is used for the determination of focal length and distortion. To illustrate this and to give an idea of the definiteness with which a given row can be selected as superior to the others, a complete record of the resolving power, as read from a typical test negative, is given in schematic form in table 1. Under the headings "Tangential" and "Radial" is shown the behavior of the resolving power at $5^{\circ}$ intervals, expressed in lines per millimeter of the test negative, in image planes spaced $0.15 \mathrm{~mm}$ apart. The region studied with this step-by-step process extends from an image plane $1.2 \mathrm{~mm}$ nearer the lens to an image plane $1.5 \mathrm{~mm}$ farther from the lens than the image plane selected for the determination of the equivalent focal length and which yields best average definition. The two values of the resolving power given for each image arise from two sets of patterns of parallel lines contained by the test chart. One pattern consists of lines perpendicular to a radius drawn from the center of the field, the other consists of lines parallel to the same radius. The tangential and radial resolving powers correspond, respectively, to resolving powers of the rays often referred to as meridional and sagittal, or to the primary and secondary rays, as designated by H. D. Taylor. ${ }^{3}$ The lens with which this negative was made had a nominal focal length of $81 / 4$ in. and was tested at maximum aperture, which was $f / 4$.

TABLE 1.-Resolving powers as read from a test negative for a typical f/4 lens

\begin{tabular}{|c|c|c|c|c|c|c|c|c|c|c|c|c|c|c|}
\hline \multirow{3}{*}{ Row ${ }^{1}$} & \multicolumn{7}{|c|}{$\begin{array}{c}\text { Tangential resolving power in lines per } \\
\text { millimeter }\end{array}$} & \multicolumn{7}{|c|}{$\begin{array}{l}\text { Radial resolving power in lines per } \\
\text { millimeter }\end{array}$} \\
\hline & \multicolumn{7}{|c|}{ Angular distance from axis } & \multicolumn{7}{|c|}{ Angular distance from axis } \\
\hline & $0^{\circ}$ & $5^{\circ}$ & $10^{\circ}$ & $15^{\circ}$ & $20^{\circ}$ & $25^{\circ}$ & $30^{\circ}$ & $0^{\circ}$ & $5^{\circ}$ & $10^{\circ}$ & $15^{\circ}$ & $20^{\circ}$ & $25^{\circ}$ & $30^{\circ}$ \\
\hline $\begin{array}{l}3 \\
4 \\
5\end{array}$ & $\begin{array}{l}3.5 \\
3.5 \\
5 \\
5 \\
7\end{array}$ & $\begin{array}{r}5 \\
5 \\
7 \\
10 \\
14\end{array}$ & $\begin{array}{r}7 \\
10 \\
20 \\
28 \\
28\end{array}$ & $\begin{array}{l}28 \\
28 \\
40 \\
40 \\
40\end{array}$ & $\begin{array}{l}28 \\
40 \\
40 \\
28 \\
20\end{array}$ & $\begin{array}{l}20 \\
20 \\
14 \\
14 \\
14\end{array}$ & $\begin{array}{l}14 \\
14 \\
14 \\
14 \\
14 \\
14\end{array}$ & $\begin{array}{l}3.5 \\
3.5 \\
5 \\
5 \\
7\end{array}$ & $\begin{array}{l}3.5 \\
3.5 \\
5 \\
5 \\
7\end{array}$ & $\begin{array}{r}5 \\
7 \\
7 \\
10 \\
14\end{array}$ & $\begin{array}{l}10 \\
14 \\
28 \\
40 \\
56\end{array}$ & $\begin{array}{l}56 \\
56 \\
40 \\
28 \\
20\end{array}$ & $\begin{array}{l}56 \\
56 \\
40 \\
28 \\
14\end{array}$ & $\begin{array}{l}10 \\
10 \\
14 \\
20 \\
40\end{array}$ \\
\hline $\begin{array}{l}6 \\
7 \\
8 \\
9 \\
90\end{array}$ & $\begin{array}{l}10 \\
14 \\
20 \\
28 \\
56\end{array}$ & $\begin{array}{l}20 \\
20 \\
20 \\
28 \\
40\end{array}$ & $\begin{array}{l}28 \\
28 \\
28 \\
\mathbf{4 0} \\
40\end{array}$ & $\begin{array}{l}40 \\
28 \\
20 \\
\mathbf{1 4} \\
10\end{array}$ & $\begin{array}{r}20 \\
10 \\
7 \\
y \\
5\end{array}$ & $\begin{array}{r}14 \\
14 \\
10 \\
10 \\
7\end{array}$ & $\begin{array}{l}14 \\
10 \\
10 \\
10 \\
10\end{array}$ & $\begin{array}{l}7 \\
10 \\
14 \\
20 \\
56\end{array}$ & $\begin{array}{l}10 \\
14 \\
20 \\
28 \\
40\end{array}$ & $\begin{array}{l}28 \\
28 \\
40 \\
56 \\
40\end{array}$ & $\begin{array}{l}40 \\
40 \\
14 \\
14 \\
10\end{array}$ & $\begin{array}{r}14 \\
10 \\
7 \\
7 \\
5\end{array}$ & $\begin{array}{r}10 \\
10 \\
7 \\
7 \\
5\end{array}$ & $\begin{array}{l}56 \\
56 \\
56 \\
40 \\
40\end{array}$ \\
\hline 1112 & $\begin{array}{l}56 \\
56 \\
40 \\
40 \\
40\end{array}$ & $\begin{array}{l}40 \\
40 \\
40 \\
14 \\
10\end{array}$ & $\begin{array}{r}28 \\
14 \\
10 \\
10 \\
7\end{array}$ & $\begin{array}{l}7 \\
5 \\
5 \\
5 \\
3.5\end{array}$ & $\begin{array}{l}5 \\
5 \\
5 \\
3.5 \\
3.5\end{array}$ & $\begin{array}{l}7 \\
5 \\
5 \\
5 \\
5\end{array}$ & $\begin{array}{r}10 \\
7 \\
7 \\
7 \\
5\end{array}$ & $\begin{array}{l}56 \\
40 \\
40 \\
40 \\
28\end{array}$ & $\begin{array}{l}56 \\
40 \\
40 \\
40 \\
20\end{array}$ & $\begin{array}{l}40 \\
20 \\
14 \\
10 \\
10\end{array}$ & $\begin{array}{l}7 \\
5 \\
5 \\
5 \\
3.5\end{array}$ & $\begin{array}{l}5 \\
5 \\
3.5 \\
3.5 \\
3.5\end{array}$ & \begin{tabular}{l|}
5 \\
5 \\
3.5 \\
3.5 \\
3.5
\end{tabular} & $\begin{array}{r}20 \\
14 \\
14 \\
10 \\
7\end{array}$ \\
\hline 16 & $\begin{array}{l}28 \\
20 \\
10 \\
3.5\end{array}$ & $\begin{array}{r}10 \\
7 \\
7 \\
5\end{array}$ & $\begin{array}{l}7 \\
5 \\
5 \\
3.5\end{array}$ & $\begin{array}{r}3.5 \\
3.5 \\
3.5 \\
--.--\end{array}$ & 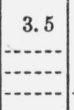 & $\begin{array}{l}5 \\
5 \\
3.5 \\
-\end{array}$ & $\begin{array}{l}5 \\
5 \\
5 \\
5\end{array}$ & $\begin{array}{r}20 \\
14 \\
10 \\
5\end{array}$ & $\begin{array}{l}14 \\
7 \\
5 \\
3.5\end{array}$ & $\begin{array}{l}5 \\
5 \\
3.5 \\
3.5\end{array}$ & $\begin{array}{l}3.5 \\
3.5 \\
-\end{array}$ & \begin{tabular}{c}
3.5 \\
\hdashline.-- \\
.-- \\
\end{tabular} & 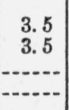 & $\begin{array}{l}7 \\
5 \\
5 \\
5\end{array}$ \\
\hline
\end{tabular}

119 rows of images are taken on a single negative in the test of a single lens. Row 1 is nearest to the lens. Readings are taken in image planes spaced $0.15 \mathrm{~mm}$ apart for a range of $2.70 \mathrm{~mm}$ through the region of best focus. Tangential and radial resolving powers are tabulated separately for greater clarity. Row 9 shows the resolving power in that image plane adjudged to yield best average definition.

A System of Applied Optics, p. 115 (Macmillan and Co., Ltd., 1906). 
Examination of table 1 shows that the resolving power starts low, rises to a maximum, and drops again as one moves into and out of focus. This behavior is found for both tangential and radial patterns for each angle. The regions of maximum resolving power for the various angles do not all lie in the same image plane because of curvature of field. For this lens, curvature of field produces an axial difference of approximately $1 \mathrm{~mm}$ in the positions of best focus at $0^{\circ}$ and $15^{\circ}$. Moreover, the regions of maximum resolving power for tangential and radial patterns do not necessarily lie in the same plane for any given angle because of astigmatism. In this instance, astigmatism produces an axial difference of approximately $0.1 \mathrm{~mm}$ in the positions of best tangential and radial resolving power at $0^{\circ}$ and $15^{\circ}$.

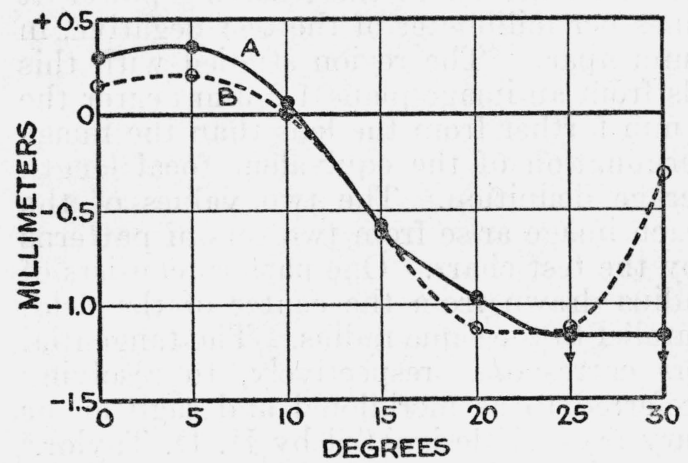

FigURE 1.-These curves show the variation of the position of best imagery as measured along the axis of the lens.

The data are derived from the test negative shown in table 1. Curve $A$ represents the position of best tangential imagery at every $5^{\circ}$ interval from $0^{\circ}$ to $30^{\circ}$. Curve $B$ shows the position of best radial imagery at every $5^{\circ}$ interval from $0^{\circ}$ to $30^{\circ}$. Row 9 in table 1 is taken as the zero of ordinates. The arrows that qualify two points on the tangential curve signify that at these angular separations from the axis the position of best tangential imagery may lie outside the region traversed by the plate. and $30^{\circ}$ are qualified by arrows which signify that for these angles the shows the position of maximum resolving power for tangential and radial imagery every $5^{\circ}$ from $0^{\circ}$ to $30^{\circ}$. The data for the graph were obtained from table 1. The zero ordinate is arbitrarily chosen as corresponding to row 9 , which was the row used in determining the reported E. F. L. The ordinates in the graph are the number of millimeters which the photographic plate must be moved toward or from the lens, as measured from the image plane of the reported E. F. L., to get best resolution at any specified angle. The points on the tangential curve for $25^{\circ}$ image plane of best tangential definition may be outside the region traversed by the photographic plate during the test. It may be noted that these curves, as might be expected, closely resemble typical curves of primary and secondary curvature. The difference in the ordinates at each angle gives a measure of the astigmatism.

These considerations show that a compromise setting of the lens is necessary to obtain fair usable imagery across the entire negative. To attain this end, one must have some criterion to facilitate the selection of the best row on the test negative, and one must be sure that on repetition of the test one would arrive at sensibly the same value of E. F. L. each time. This goal has been attained by the adoption of two criteria. First, rows are selected for which the resolving power, for both tangential and radial imagery and for all images in the rows selected, is, if possible, not less than 7 lines per millimeter. ${ }^{4}$ Second, from all rows which satisfy the first condition, a row is selected for which the resolving power on the axis is as high as possi-

4 The value, 7 lines per millimeter, herein used as the lower limit of acceptable resolving power was sug. gested from tentative values for minimum resolving power given on p. 19 and 20 of Standard Specifications (2d ed.) published by the American Society of Photogrammetry on July 22, 1936. 
ble, and preferably not less than 15 lines per millimeter. Selection in this manner generally gives the best average definition across the entire field. In some cases, where the tests have shown that the resolving power of a given lens was very low, it has been necessary to drop the first condition below 7 lines per millimeter at $20^{\circ}$ and $25^{\circ}$ in order to maintain the resolving power in the center of the field at 15 lines per millimeter. However, when this is necessary, there can be little doubt that such a lens is poor indeed and ought not to be used in aerial mapping.

Using these two criteria in studying the test negative whose resolving powers are tabulated in table 1 , row 9 is selected. It may be noted that rows $5,6,7,8$, and 9 all satisfy the first condition; however, application of the second condition eliminates all except row 9. Row 10 shows much better definition on the axis than row 9 , but selection of row 10 would violate the first condition and would result in poor imagery at $20^{\circ}$ and $25^{\circ}$. If row 8 had been selected, the second condition would be violated and the central imagery would be inferior to the central imagery of row 9 .

The marked differences that exist between the regions of best focus as measured along the axis of the lens can easily give rise to differences in the measured values of E. F. L. of a lens, depending upon the manner in which the lens is focused in a camera. It is clear that if one depends on axial definition only in setting the lens in a camera, then poor definition will result at the wider angles. Conversely, if too much emphasis is placed upon securing best imagery at the edge of the field or at some point midway between the edge and center of the field, then either the central portion or some intermediate zone will probably be poor; possibly poor definition will be present in both places at once (for example, in row 2 of table 1 , good imagery at $20^{\circ}$ is accompanied by very poor imagery at $0^{\circ}$ and $5^{\circ}$, and by only fair imagery at $10^{\circ}$ and $30^{\circ}$ ). However, if care is taken in adjusting the lens in an aerial camera so that useful imagery is present across the entire field, then it is probable that different workers using this same criterion would set the lens to within $0.10 \mathrm{~mm}$ of the same position each time, and for that position the corresponding E. F. L. would be that which is found by this best resolving-power method. This method of setting the lens can be used where it is not readily practicable to use the back focal length in mechanically setting the lens in the camera. The back focal length which is customarily given in the reports of the National Bureau of Standards is the distance from the back surface of the lens to the image plane of best average definition.

\section{RESOLVING POWERS FOR TYPICAL AIRPLANE- CAMERA LENSES}

When selection is made of the image plane that yields the best average resolving power and when the manner in which the resolution varies with angular separation from the axis is studied, it is found that the pattern of variation for a particular lens shows striking similarity to the patterns exhibited by other lenses of the same type, despite the differences in workmanship which are unavoidably present and which do introduce considerable differences in the quality of lenses made according to the same specification. This pattern is a definite property of the lens and is best shown by the accompanying tables of tangential 
and radial resolving powers. These tables are compiled from a study of many lenses, and the resolving powers therein are reported for image planes both nearer to and farther from the lens than the image plane considered to have the best average resolving power. In one set of tables, the behavior of $30 \mathrm{f} / 4$ lenses of foreign manufacture is shown. In the other sets is shown the behavior of $10 f / 4$ and $20 f / 6.8$ lenses of domestic manufacture.

When these tables are considered, several factors are to be borne in mind. First, the test charts used are so designed that the number of lines to the millimeter as recorded on the test negative form the approximately geometrical series $3.5,5,7,10,14,20,28,40$, and 56 . Hence, these are the only values of resolving power which can appear on these test negatives. Second, the upper limit of 56 lines to the millimeter was selected as being certainly equal to if not greater than the limit of resolution of the emulsions commonly used in airplanecamera films; the theoretical resolving power of these lenses is much greater than 56 lines per millimeter. Third, the value reported for any image means that not only is that particular pattern clearly resolved but that all coarser patterns are also clearly resolved; this precaution is necessary to rule out false values of the resolving power. It frequently happens that a fine pattern may appear resolved when coarser patterns in the same image are unresolved. Careful inspection of the fine patterns resolved in these cases reveals that the number of lines present in the pattern on the negative do not agree with the number appearing in the original on the test chart. No thorough analysis of the causes of this phenomenon has yet been made, but preliminary work along these lines indicates that this false resolving power may arise from diffraction effects or the character of the chromatic aberration. Finally, these tests are made with a yellow filter $(K-3)$ over the test charts, so that the test conditions are comparable with the conditions that the lens encounters in practice, and the resolving powers obtained under these conditions are not as great as would be obtained with monochromatic light.

Table 2 lists the resolving powers for tangential and radial imagery at $5^{\circ}$ intervals from $0^{\circ}$ to $30^{\circ}$ for $10 \mathrm{f} / 4$ lenses of domestic manufacture. This is a three-part table and shows the resolving power in three image planes lying at different distances from the lens. Table $2(a)$ shows the resolving power in an image plane $0.5 \mathrm{~mm}$ farther from the lens than the image plane of best average definition. Table $2(b)$ shows the resolving power in the image plane that is adjudged to give best average definition and which is used in determining the reported equivalent focal length. Table $2(c)$ shows the resolving power in an image plane $0.5 \mathrm{~mm}$ nearer to the lens than the image plane of best average definition. Cursory examination of this table shows a striking consistency, from lens to lens, of the manner in which the resolving power for a particular image plane varies across the field.

To make this consistency quantitatively discernible, a series of occurrence tables have been prepared. These occurrence tables list for each angular separation from the axis the number of occurrences of each of the series of definite values of the resolving power in lines per millimeter and give a complete, concise picture of the behavior of the 10 lenses as a group. Occurrence tables for these 10 lenses have been formed for each of the three image planes studied and are 
assembled in table 3. This table makes possible comparison of the manner in which resolving power varies across the entire image plane for tangential and radial imagery. The table also permits ready comparison of resolving powers in the three image planes of images lying at equal angular separations from the axis of the lens but at different distances from the lens. In table 4 are tabulated the average resolving power for each image plane for each angular separation from the axis for both tangential and radial imagery. These averages are derived from table 3 and cover the 10 lenses. These average resolving powers are those which one might reasonably expect to get from any lens of this type.

TABLE 2.-Resolving powers of $10 \mathrm{f} / 4$ lenses of domestic manufacture

\begin{tabular}{|c|c|c|c|c|c|c|c|c|c|c|c|c|c|c|}
\hline \multirow{2}{*}{$\begin{array}{c}\text { Lens } \\
\text { number }\end{array}$} & \multicolumn{7}{|c|}{$\begin{array}{c}\text { Tangential resolving power in lines per } \\
\text { millimeter } \\
\text { Angular distance from axis }\end{array}$} & \multicolumn{7}{|c|}{$\begin{array}{l}\text { Radial resolving power in lines per millimeter } \\
\text { Angular distance from axis }\end{array}$} \\
\hline & $0^{\circ}$ & $5^{\circ}$ & $10^{\circ}$ & $15^{\circ}$ & $20^{\circ}$ & $25^{\circ}$ & $30^{\circ}$ & $0^{\circ}$ & 5 & $10^{\circ}$ & $15^{\circ}$ & $20^{\circ}$ & $25^{\circ}$ & $30^{\circ}$ \\
\hline
\end{tabular}

(a) Image plane $0.5 \mathrm{~mm}$ farther from the lens than the image plane of best average resolving power

\begin{tabular}{|c|c|c|c|c|c|c|c|c|c|c|c|c|c|c|}
\hline $\begin{array}{l}1 \\
3 \\
3 \\
3\end{array}$ & $\begin{array}{l}20 \\
20 \\
40 \\
56 \\
56\end{array}$ & $\begin{array}{l}28 \\
14 \\
40 \\
40 \\
40\end{array}$ & $\begin{array}{l}28 \\
14 \\
28 \\
14 \\
10\end{array}$ & $\begin{array}{r}14 \\
14 \\
14 \\
7 \\
7\end{array}$ & $\begin{array}{r}7 \\
10 \\
5 \\
5 \\
5\end{array}$ & $\begin{array}{l}14 \\
5 \\
5 \\
3.5 \\
7\end{array}$ & $\begin{array}{r}7 \\
10 \\
5 \\
5 \\
10\end{array}$ & $\begin{array}{l}20 \\
14 \\
40 \\
56 \\
40\end{array}$ & $\begin{array}{l}20 \\
14 \\
40 \\
40 \\
40\end{array}$ & $\begin{array}{l}14 \\
14 \\
40 \\
20 \\
14\end{array}$ & $\begin{array}{r}10 \\
14 \\
7 \\
5 \\
7\end{array}$ & $\begin{array}{r}7 \\
10 \\
5 \\
5 \\
5\end{array}$ & $\begin{array}{r}10 \\
7 \\
5 \\
5 \\
5\end{array}$ & $\begin{array}{l}28 \\
40 \\
56 \\
40 \\
56\end{array}$ \\
\hline $\begin{array}{l}6 \\
8 \\
9 \\
10\end{array}$ & $\begin{array}{l}56 \\
56 \\
28 \\
40 \\
40\end{array}$ & $\begin{array}{l}40 \\
56 \\
28 \\
40 \\
40\end{array}$ & $\begin{array}{l}20 \\
28 \\
28 \\
20 \\
14\end{array}$ & $\begin{array}{r}10 \\
7 \\
10 \\
7 \\
7\end{array}$ & $\begin{array}{l}5 \\
5 \\
5 \\
5 \\
5\end{array}$ & $\begin{array}{l}7 \\
5 \\
5 \\
5 \\
7\end{array}$ & $\begin{array}{r}10 \\
7 \\
7 \\
7 \\
7 \\
10\end{array}$ & $\begin{array}{l}40 \\
40 \\
28 \\
40 \\
40\end{array}$ & $\begin{array}{l}40 \\
56 \\
40 \\
40 \\
40\end{array}$ & $\begin{array}{l}20 \\
40 \\
40 \\
20 \\
20\end{array}$ & $\begin{array}{r}5 \\
7 \\
14 \\
5 \\
5\end{array}$ & $\begin{array}{l}5 \\
5 \\
5 \\
5 \\
5\end{array}$ & $\begin{array}{l}5 \\
7 \\
5 \\
5 \\
5\end{array}$ & $\begin{array}{l}56 \\
56 \\
56 \\
56 \\
56\end{array}$ \\
\hline
\end{tabular}

(b) Image plane of best average resolving power

\begin{tabular}{|c|c|c|c|c|c|c|c|c|c|c|c|c|c|c|}
\hline $\begin{array}{l}1 \\
2 \\
3\end{array}$ & $\begin{array}{l}56 \\
56 \\
28 \\
28 \\
40\end{array}$ & $\begin{array}{l}40 \\
56 \\
56 \\
40 \\
40\end{array}$ & $\begin{array}{l}28 \\
40 \\
40 \\
40 \\
56\end{array}$ & $\begin{array}{l}10 \\
28 \\
20 \\
14 \\
14\end{array}$ & $\begin{array}{r}7 \\
14 \\
10 \\
7 \\
14\end{array}$ & $\begin{array}{r}14 \\
14 \\
7 \\
5 \\
14\end{array}$ & $\begin{array}{r}14 \\
14 \\
10 \\
7 \\
14\end{array}$ & $\begin{array}{l}56 \\
56 \\
20 \\
28 \\
40\end{array}$ & $\begin{array}{l}40 \\
56 \\
56 \\
40 \\
40\end{array}$ & $\begin{array}{l}40 \\
40 \\
40 \\
56 \\
56\end{array}$ & $\begin{array}{l}28 \\
28 \\
40 \\
20 \\
10\end{array}$ & $\begin{array}{r}10 \\
14 \\
20 \\
7 \\
10\end{array}$ & $\begin{array}{r}10 \\
28 \\
10 \\
7 \\
10\end{array}$ & $\begin{array}{l}40 \\
20 \\
28 \\
56 \\
28\end{array}$ \\
\hline $\begin{array}{l}6 \\
7 \\
9 \\
9\end{array}$ & $\begin{array}{l}28 \\
20 \\
40 \\
40 \\
40\end{array}$ & $\begin{array}{l}40 \\
56 \\
40 \\
28 \\
56\end{array}$ & $\begin{array}{l}56 \\
40 \\
28 \\
40 \\
40\end{array}$ & $\begin{array}{l}14 \\
14 \\
14 \\
20 \\
14\end{array}$ & $\begin{array}{r}14 \\
7 \\
10 \\
10 \\
7\end{array}$ & $\begin{array}{r}10 \\
7 \\
10 \\
7 \\
10\end{array}$ & $\begin{array}{l}14 \\
10 \\
10 \\
14 \\
14\end{array}$ & $\begin{array}{l}40 \\
20 \\
40 \\
40 \\
40\end{array}$ & $\begin{array}{l}56 \\
56 \\
28 \\
28 \\
56\end{array}$ & $\begin{array}{l}40 \\
56 \\
28 \\
40 \\
40\end{array}$ & $\begin{array}{l}10 \\
28 \\
28 \\
20 \\
20\end{array}$ & $\begin{array}{r}7 \\
10 \\
10 \\
10 \\
7\end{array}$ & $\begin{array}{l}10 \\
10 \\
10 \\
10 \\
10\end{array}$ & $\begin{array}{l}40 \\
28 \\
20 \\
28 \\
28\end{array}$ \\
\hline
\end{tabular}

(c) Image plane $0.5 \mathrm{~mm}$ nearer to the lens than the image plane of best average resolving power

\begin{tabular}{|c|c|c|c|c|c|c|c|c|c|c|c|c|c|c|}
\hline 1. & $\begin{array}{r}28 \\
20 \\
7 \\
7 \\
10\end{array}$ & $\begin{array}{r}20 \\
20 \\
7 \\
10 \\
10\end{array}$ & $\begin{array}{l}14 \\
28 \\
28 \\
40 \\
28\end{array}$ & $\begin{array}{l}10 \\
20 \\
40 \\
40 \\
56\end{array}$ & $\begin{array}{l}10 \\
14 \\
20 \\
14 \\
20\end{array}$ & $\begin{array}{l}10 \\
20 \\
10 \\
10 \\
20\end{array}$ & $\begin{array}{l}14 \\
20 \\
14 \\
14 \\
20\end{array}$ & $\begin{array}{r}28 \\
20 \\
7 \\
7 \\
10\end{array}$ & $\begin{array}{r}28 \\
28 \\
7 \\
10 \\
10\end{array}$ & $\begin{array}{l}28 \\
40 \\
14 \\
20 \\
28\end{array}$ & $\begin{array}{l}28 \\
28 \\
40 \\
56 \\
56\end{array}$ & $\begin{array}{l}14 \\
28 \\
40 \\
20 \\
20\end{array}$ & $\begin{array}{l}14 \\
28 \\
40 \\
10 \\
28\end{array}$ & $\begin{array}{l}40 \\
10 \\
10 \\
14 \\
10\end{array}$ \\
\hline $\begin{array}{l}6 \\
7 \\
8 \\
9 \\
9 \\
10\end{array}$ & $\begin{array}{r}7 \\
7 \\
10 \\
10 \\
14\end{array}$ & $\begin{array}{r}10 \\
7 \\
14 \\
10 \\
20\end{array}$ & $\begin{array}{l}20 \\
28 \\
28 \\
28 \\
40\end{array}$ & $\begin{array}{l}40 \\
40 \\
20 \\
40 \\
28\end{array}$ & $\begin{array}{l}14 \\
20 \\
20 \\
28 \\
10\end{array}$ & $\begin{array}{l}14 \\
10 \\
14 \\
14 \\
14\end{array}$ & $\begin{array}{l}20 \\
14 \\
14 \\
20 \\
14\end{array}$ & $\begin{array}{r}7 \\
7 \\
7 \\
10 \\
14\end{array}$ & $\begin{array}{r}10 \\
7 \\
7 \\
10 \\
20\end{array}$ & $\begin{array}{l}28 \\
28 \\
14 \\
28 \\
56\end{array}$ & $\begin{array}{l}56 \\
56 \\
28 \\
56 \\
40\end{array}$ & $\begin{array}{l}20 \\
28 \\
40 \\
28 \\
14\end{array}$ & $\begin{array}{l}20 \\
28 \\
20 \\
40 \\
10\end{array}$ & $\begin{array}{l}10 \\
10 \\
10 \\
10 \\
14\end{array}$ \\
\hline
\end{tabular}

In figure 2, the data from table 4 are graphed to give a clear picture of these characteristics. Although curve $B$, which is the curve of best definition for both tangential and radial imagery, does not always lie above curves $A$ and $C$, which show the definition at the other two 
image distances, there can be little doubt that this image plane is to be preferred. When tangential definition is considered, curve $B$ lies above curve $A$ at all points save on the axis, where $A$ has a negligible advantage. Curve $B$ lies below curve $C$ from $15^{\circ}$ to $30^{\circ}$, inclusive, but the advantage which $C$ has over $B$ for this region is nullified by virtue of the large differences in favor of $B$ for the region $0^{\circ}$ to $10^{\circ}$, in-

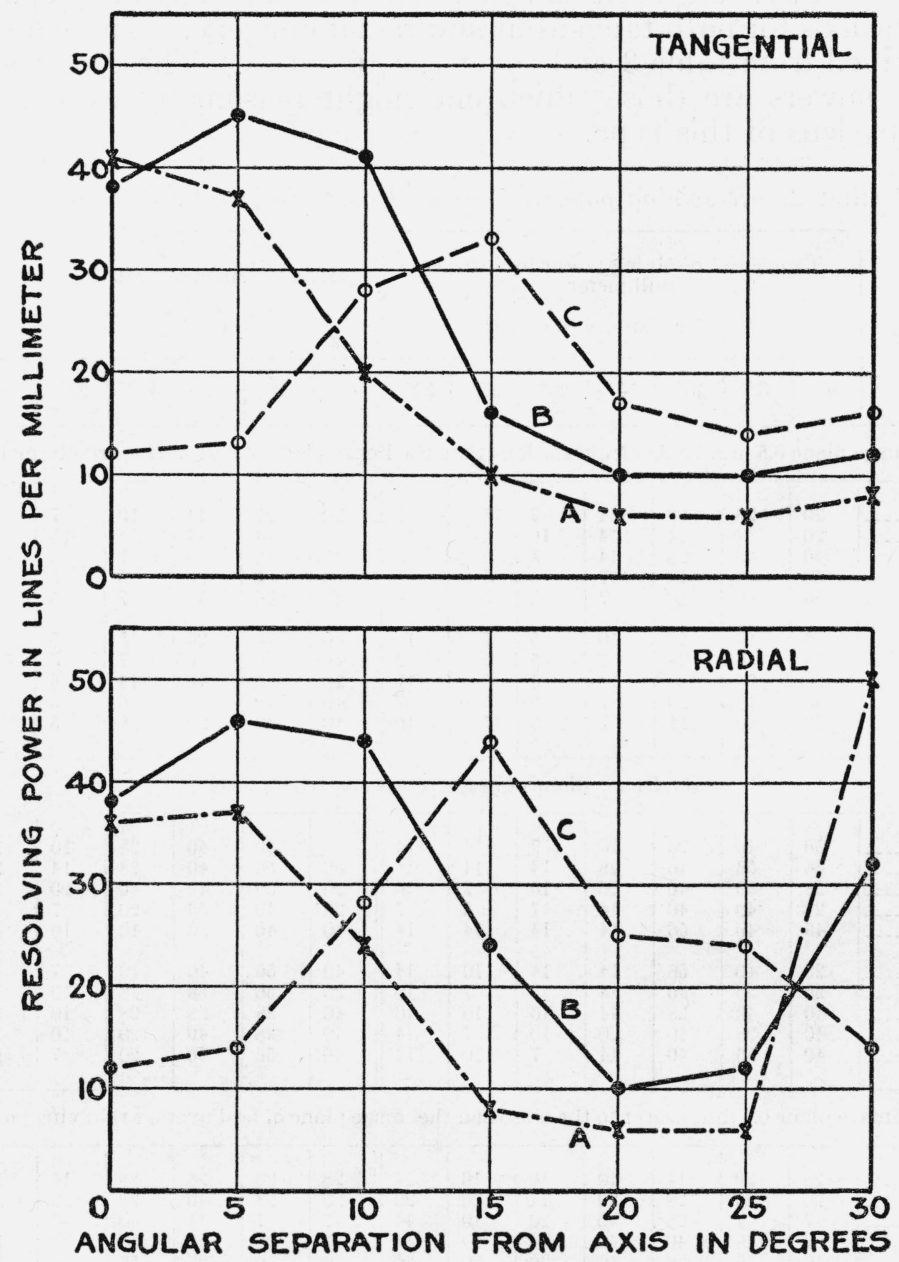

FIGURE 2.-Graphs showing the tangential and radial resolving powers for $10 \mathrm{f} / 4$ lenses of domestic manufacture.

$A$, image plane $0.5 \mathrm{~mm}$ farther from the lens than the plane of best average definition; $B$, image plane of best average definition; $C$, image plane $0.5 \mathrm{~mm}$ nearer to the lens than the plane of best average definition.

clusive. For radial imagery, curve $B$ is above curve $A$ at all points save at $30^{\circ}$, and here one finds good imagery for both image planes, so that the advantage which $B$ holds for this separation from the axis is nullified by its inferior definition at all other points. Curve $C$ is superior to $A$ at $15^{\circ}, 20^{\circ}$, and $25^{\circ}$, but is very inferior at $0^{\circ}, 5^{\circ}$, and $30^{\circ}$ and somewhat so at $10^{\circ}$. 
TABLE 3.-Occurrence tables showing the distribution of maximal values of the resolving power for three image planes

\begin{tabular}{|c|c|c|c|c|c|c|c|c|c|c|c|c|c|c|}
\hline \multirow{4}{*}{$\begin{array}{l}\text { Resolving } \\
\text { power in } \\
\text { lines per mm }\end{array}$} & \multicolumn{14}{|c|}{$\begin{array}{c}\text { Distribution of maximal values of the resolving power for the } 10 \mathrm{f} / 4 \text { lenses of domestic } \\
\text { manufacture }\end{array}$} \\
\hline & \multicolumn{7}{|c|}{ Tangential. } & \multicolumn{7}{|c|}{ Radial. } \\
\hline & \multicolumn{7}{|c|}{ Angular distance from axis. } & \multicolumn{7}{|c|}{ Angular distance from axis. } \\
\hline & $0^{\circ}$ & $5^{\circ}$ & $10^{\circ}$ & $15^{\circ}$ & $20^{\circ}$ & $25^{\circ}$ & $30^{\circ}$ & $0^{\circ}$ & $5^{\circ}$ & $10^{\circ}$ & $15^{\circ}$ & $20^{\circ}$ & $25^{\circ}$ & $30^{\circ}$ \\
\hline
\end{tabular}

(a) Image plane $0.5 \mathrm{~mm}$ farther from the lens than the image plane of best average definition

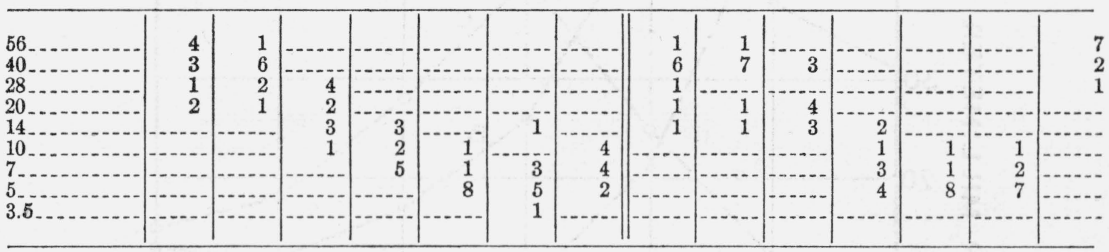

(b) Image plane of best average definition

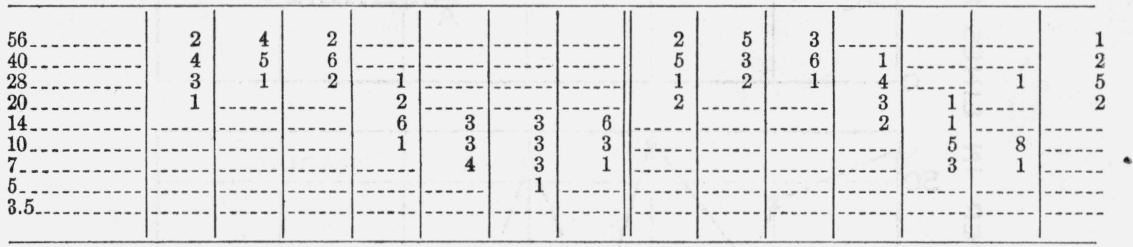

(c) Image plane $0.5 \mathrm{~mm}$ nearer to the lens than the image plane of best average definition

\begin{tabular}{|c|c|c|c|c|c|c|c|c|c|c|c|c|c|c|}
\hline $\begin{array}{l}56 \\
40\end{array}$ & & & & $\begin{array}{l}1 \\
5\end{array}$ & & & & & & $\begin{array}{l}1 \\
1\end{array}$ & $\begin{array}{l}5 \\
2\end{array}$ & & & \\
\hline 28 & 1 & (n) & 6 & 1 & 1 & & & 1 & 2 & $\begin{array}{l}1 \\
5\end{array}$ & 3 & 3 & 3 & \\
\hline . & 1 & 3 & 1 & 2 & 4 & 2 & 4 & 1 & 1 & 1 & -...... & 3 & 2 & \\
\hline - & 1 & 1 & 1 & & 3 & 4 & 6 & 1 & & 2 & - & 2 & 1 & \\
\hline $10 \ldots$ & 3 & 4 & $|-\ldots-|$ & 1 & 2 & 4 & $-\ldots$ & 2 & 4 & - & $-\ldots$ & - & 2 & \\
\hline (n) & 4 & 2 & 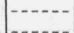 & $-\cdots-1$ & $-\cdots$ & (n)- & -non & 5 & 3 & (-...- & $-\cdots$ & $-\cdots$ & $-\cdots-1$ & \\
\hline & ........ & $\ldots$ & $\ldots$ & $-\ldots$ & $\ldots$ & . & $\ldots$ & 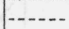 & -........ & $\ldots$ & $-\ldots$ & $\ldots$ & $\ldots$ & (n) \\
\hline & & & & & & & & & & & & & & \\
\hline
\end{tabular}

TABLE 4.-Average resolving powers for the $10 \mathrm{f} / 4$ lenses of domestic manufacture

\begin{tabular}{|c|c|c|c|c|c|c|c|c|c|c|c|c|c|c|}
\hline \multirow{3}{*}{ Image plane } & \multirow{2}{*}{\multicolumn{7}{|c|}{$\begin{array}{l}\text { Tangential resolving power in lines per } \\
\text { millimeter. } \\
\text { Angular distance from axis. }\end{array}$}} & \multirow{2}{*}{\multicolumn{7}{|c|}{$\begin{array}{l}\text { Radial resolving power in lines per } \\
\text { millimeter. } \\
\text { Angular distance from axis. }\end{array}$}} \\
\hline & & & & & & & & & & & & & & \\
\hline & $0^{\circ}$ & $5^{\circ}$ & $10^{\circ}$ & $15^{\circ}$ & $20^{\circ}$ & $25^{\circ}$ & $30^{\circ}$ & $0^{\circ}$ & $5^{\circ}$ & $10^{\circ}$ & $15^{\circ}$ & $20^{\circ}$ & $25^{\circ}$ & $30^{\circ}$ \\
\hline$(a)$ & 41 & 37 & 20 & 10 & 6 & 6 & 8 & 36 & 37 & 24 & 8 & 6 & 6 & 50 \\
\hline (b) $\ldots$ & 38 & 45 & 41 & 16 & 10 & 10 & 12 & 38 & 46 & 44 & 24 & 10 & 12 & 32 \\
\hline (c) $\ldots$ & 12 & 13 & 28 & 33 & 17 & 14 & 16 & 12 & 14 & 28 & 44 & 25 & 24 & 14 \\
\hline
\end{tabular}

(a), Image plane $0.5 \mathrm{~mm}$ farther from the lens than the image plane of best average definition.

(b), Image plane of best average definition.

(c), Image plane $0.5 \mathrm{~mm}$ nearer to the lens than the image plane of best average definition.

Table 5 lists the resolving powers at $5^{\circ}$ intervals in the image plane of best average definition for $30 \mathrm{f} / 4$ lenses of foreign manufacture. In table 6 are grouped occurrence tables for three image planes that lie at different distances from the lens. Table 7 lists the average $146065-39-8$ 
resolving power for each angular separation from the axis for each image plane for both tangential and radial imagery.

In figure 3 the data from table 7 are graphed to present a clear picture of these characteristics. In these graphs of both tangential and radial resolving power, it is evident that with one exception the

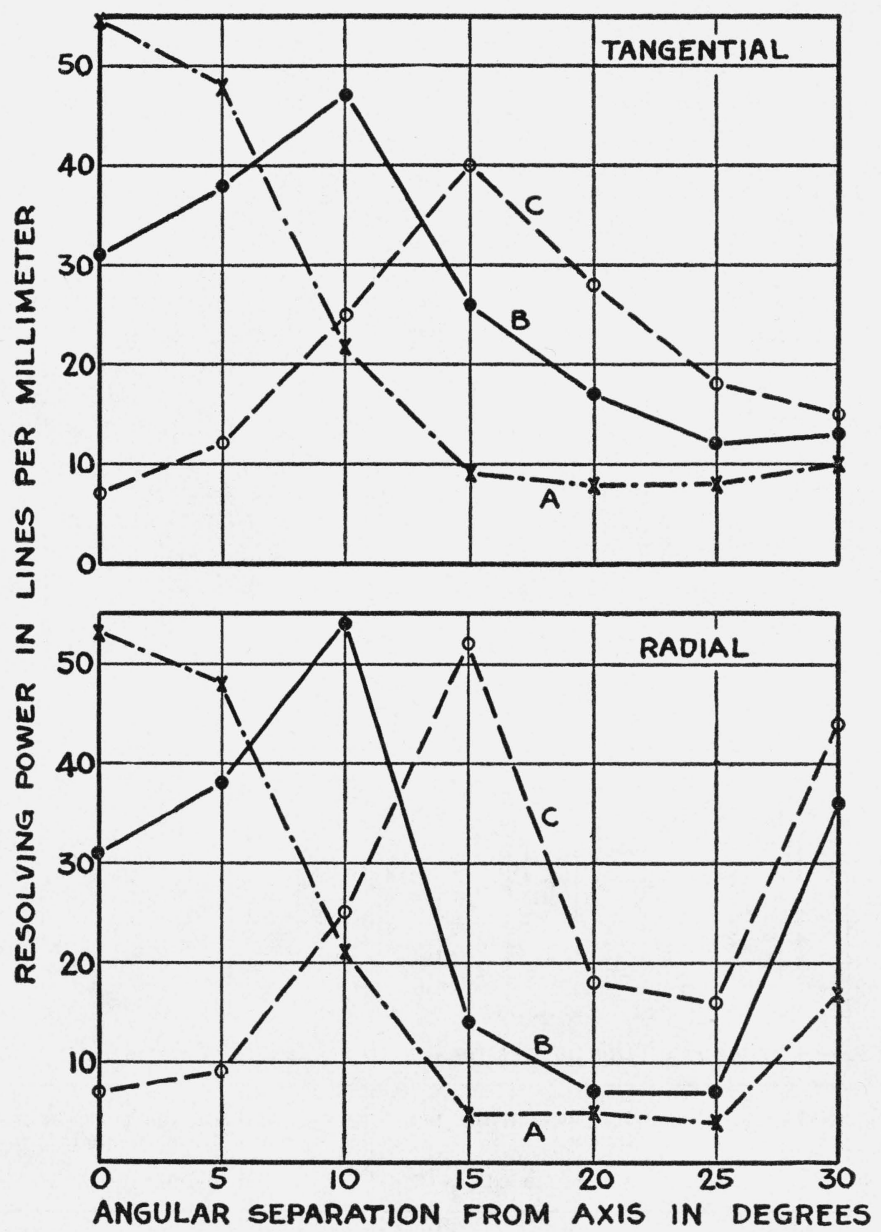

FIGURE 3.-Graphs showing the tangential and radial resolving powers for $30 \mathrm{f} / 4$ lenses of foreign manufacture.

$A$, image plane $0.5 \mathrm{~mm}$ farther from the lens than the plane of best average definition. $B$, image plane of best average definition. $C$, image plane $0.5 \mathrm{~mm}$ nearer to the lens than the plane of best average definition.

curve $B$, which corresponds to the image plane of best average resolving power, lies between the curves for the other two image planes. This exception is at $10^{\circ}$, where the value of the resolving power of curve $B$ is by a considerable margin the highest of the three. The graph shows that if the image plane nearest to the lens were selected the resolving power beyond $15^{\circ}$ would greatly improve. However, the values from $0^{\circ}$ to $10^{\circ}$ would drop so rapidly as to render the advantage very doubtful. In a similar manner, if the image plane 
farthest from the lens were selected, the resolving power at $0^{\circ}$ and $5^{\circ}$ would improve, while from $15^{\circ}$ to $30^{\circ}$ there would be a definite reduction. In particular, the radial values at $20^{\circ}$ and $25^{\circ}$ would fall below seven lines to the millimeter.

TABLE 5.-Resolving power of $30 \mathrm{f} / 4$ lenses of foreign manufacture in the image plane of best average resolving power

\begin{tabular}{|c|c|c|c|c|c|c|c|c|c|c|c|c|c|c|}
\hline \multirow[t]{2}{*}{ Lens $\underset{\text { ber }}{\text { num- }}$} & \multicolumn{7}{|c|}{$\begin{array}{l}\text { Tangential resolving power in lines per mil- } \\
\text { limeter. } \\
\text { Angular distance from axis. }\end{array}$} & \multicolumn{7}{|c|}{$\begin{array}{l}\text { Radial resolving power in lines per milli- } \\
\text { meter. } \\
\text { Angular distance from axis. }\end{array}$} \\
\hline & $0^{\circ}$ & $5^{\circ}$ & $10^{\circ}$ & $15^{\circ}$ & $20^{\circ}$ & $25^{\circ}$ & $30^{\circ}$ & $0^{\circ}$ & $5^{\circ}$ & $10^{\circ}$ & $15^{\circ}$ & $20^{\circ}$ & $25^{\circ}$ & $30^{\circ}$ \\
\hline & $\begin{array}{l}40 \\
20 \\
28 \\
40 \\
40\end{array}$ & $\begin{array}{l}40 \\
40 \\
28 \\
40 \\
56\end{array}$ & $\begin{array}{l}56 \\
40 \\
56 \\
56 \\
56\end{array}$ & $\begin{array}{l}40 \\
28 \\
28 \\
40 \\
40\end{array}$ & $\begin{array}{l}20 \\
20 \\
14 \\
28 \\
28\end{array}$ & $\begin{array}{l}14 \\
14 \\
10 \\
20 \\
14\end{array}$ & $\begin{array}{l}14 \\
20 \\
10 \\
20 \\
20\end{array}$ & $\begin{array}{l}40 \\
20 \\
28 \\
28 \\
40\end{array}$ & $\begin{array}{l}56 \\
28 \\
28 \\
56 \\
56\end{array}$ & $\begin{array}{l}56 \\
40 \\
56 \\
56 \\
56\end{array}$ & $\begin{array}{l}10 \\
20 \\
28 \\
10 \\
10\end{array}$ & $\begin{array}{l}7 \\
7 \\
7 \\
7 \\
7\end{array}$ & $\begin{array}{l}7 \\
7 \\
7 \\
7 \\
7\end{array}$ & $\begin{array}{l}20 \\
40 \\
40 \\
40 \\
40\end{array}$ \\
\hline $\begin{array}{l}6 \\
7 \\
9 \\
9\end{array}$ & $\begin{array}{l}28 \\
40 \\
28 \\
20 \\
20\end{array}$ & $\begin{array}{l}40 \\
40 \\
40 \\
40 \\
40\end{array}$ & $\begin{array}{l}56 \\
56 \\
56 \\
56 \\
56\end{array}$ & $\begin{array}{l}40 \\
28 \\
40 \\
28 \\
28\end{array}$ & $\begin{array}{l}28 \\
14 \\
28 \\
14 \\
20\end{array}$ & $\begin{array}{r}20 \\
5 \\
20 \\
7 \\
14\end{array}$ & $\begin{array}{r}14 \\
5 \\
10 \\
7 \\
14\end{array}$ & $\begin{array}{l}20 \\
40 \\
28 \\
20 \\
20\end{array}$ & $\begin{array}{l}40 \\
56 \\
40 \\
28 \\
40\end{array}$ & $\begin{array}{l}56 \\
56 \\
56 \\
56 \\
56\end{array}$ & $\begin{array}{r}10 \\
7 \\
10 \\
14 \\
10\end{array}$ & $\begin{array}{l}7 \\
5 \\
7 \\
5 \\
7\end{array}$ & $\begin{array}{l}7 \\
5 \\
7 \\
5 \\
7\end{array}$ & $\begin{array}{r}40 \\
7 \\
20 \\
40 \\
40\end{array}$ \\
\hline 11 & $\begin{array}{l}28 \\
40 \\
40 \\
14 \\
40\end{array}$ & $\begin{array}{l}40 \\
40 \\
40 \\
20 \\
40\end{array}$ & $\begin{array}{l}40 \\
56 \\
56 \\
40 \\
40\end{array}$ & $\begin{array}{l}20 \\
28 \\
20 \\
40 \\
10\end{array}$ & $\begin{array}{r}14 \\
20 \\
14 \\
20 \\
7\end{array}$ & $\begin{array}{l}10 \\
14 \\
14 \\
14 \\
10\end{array}$ & $\begin{array}{l}10 \\
10 \\
10 \\
10 \\
10\end{array}$ & $\begin{array}{l}40 \\
40 \\
40 \\
14 \\
40\end{array}$ & $\begin{array}{l}40 \\
40 \\
28 \\
20 \\
40\end{array}$ & $\begin{array}{l}56 \\
56 \\
56 \\
56 \\
56\end{array}$ & $\begin{array}{l}10 \\
10 \\
10 \\
40 \\
10\end{array}$ & $\begin{array}{r}7 \\
7 \\
7 \\
10 \\
7\end{array}$ & $\begin{array}{r}7 \\
7 \\
7 \\
10 \\
7\end{array}$ & $\begin{array}{l}40 \\
40 \\
40 \\
40 \\
40\end{array}$ \\
\hline $\begin{array}{l}16 \\
17 \\
18 \\
19\end{array}$ & $\begin{array}{l}28 \\
28 \\
40 \\
28 \\
28\end{array}$ & $\begin{array}{l}28 \\
28 \\
56 \\
40 \\
28\end{array}$ & $\begin{array}{l}40 \\
56 \\
40 \\
40 \\
56\end{array}$ & $\begin{array}{l}28 \\
14 \\
28 \\
14 \\
20\end{array}$ & $\begin{array}{r}10 \\
7 \\
20 \\
10 \\
14\end{array}$ & $\begin{array}{l}14 \\
10 \\
14 \\
10 \\
10\end{array}$ & $\begin{array}{l}14 \\
10 \\
14 \\
10 \\
10\end{array}$ & $\begin{array}{l}28 \\
20 \\
40 \\
28 \\
20\end{array}$ & $\begin{array}{l}40 \\
28 \\
40 \\
40 \\
28\end{array}$ & $\begin{array}{l}56 \\
56 \\
56 \\
40 \\
56\end{array}$ & $\begin{array}{l}14 \\
10 \\
10 \\
10 \\
10\end{array}$ & $\begin{array}{r}10 \\
7 \\
7 \\
5 \\
5\end{array}$ & $\begin{array}{r}10 \\
7 \\
7 \\
5 \\
5\end{array}$ & $\begin{array}{l}40 \\
28 \\
40 \\
28 \\
40\end{array}$ \\
\hline $\begin{array}{l}21 \\
22 \\
23 \\
25\end{array}$ & $\begin{array}{l}28 \\
40 \\
40 \\
40 \\
56\end{array}$ & $\begin{array}{l}40 \\
40 \\
56 \\
40 \\
56\end{array}$ & $\begin{array}{l}40 \\
40 \\
40 \\
40 \\
40\end{array}$ & $\begin{array}{l}28 \\
10 \\
14 \\
10 \\
40\end{array}$ & $\begin{array}{r}20 \\
7 \\
14 \\
14 \\
28\end{array}$ & $\begin{array}{l}14 \\
10 \\
10 \\
10 \\
14\end{array}$ & $\begin{array}{l}14 \\
10 \\
10 \\
10 \\
14\end{array}$ & $\begin{array}{l}28 \\
40 \\
40 \\
40 \\
56\end{array}$ & $\begin{array}{l}40 \\
40 \\
40 \\
40 \\
56\end{array}$ & $\begin{array}{l}56 \\
56 \\
56 \\
56 \\
56\end{array}$ & $\begin{array}{l}14 \\
10 \\
10 \\
10 \\
10\end{array}$ & $\begin{array}{r}7 \\
7 \\
7 \\
7 \\
10\end{array}$ & $\begin{array}{l}7 \\
7 \\
7 \\
7 \\
7\end{array}$ & $\begin{array}{l}56 \\
28 \\
40 \\
40 \\
56\end{array}$ \\
\hline 30 & $\begin{array}{l}14 \\
20 \\
20 \\
20 \\
40\end{array}$ & $\begin{array}{l}28 \\
28 \\
28 \\
28 \\
40\end{array}$ & $\begin{array}{l}28 \\
40 \\
40 \\
56 \\
40\end{array}$ & $\begin{array}{l}20 \\
28 \\
20 \\
40 \\
14\end{array}$ & $\begin{array}{r}7 \\
10 \\
7 \\
28 \\
14\end{array}$ & $\begin{array}{r}7 \\
14 \\
5 \\
20 \\
10\end{array}$ & $\begin{array}{l}14 \\
28 \\
14 \\
14 \\
10\end{array}$ & $\begin{array}{l}14 \\
20 \\
40 \\
20 \\
40\end{array}$ & $\begin{array}{l}28 \\
28 \\
28 \\
40 \\
40\end{array}$ & $\begin{array}{l}\mathbf{4 0} \\
56 \\
56 \\
56 \\
56\end{array}$ & $\begin{array}{l}14 \\
28 \\
20 \\
10 \\
28\end{array}$ & $\begin{array}{l}7 \\
7 \\
5 \\
7 \\
7\end{array}$ & $\begin{array}{l}7 \\
7 \\
5 \\
7 \\
7\end{array}$ & $\begin{array}{l}10 \\
40 \\
28 \\
28 \\
40\end{array}$ \\
\hline
\end{tabular}

TABLE 6.-Occurrence tables showing the distribution of maximal values of the resolving power for three image planes

\begin{tabular}{|c|c|c|c|c|c|c|c|c|c|c|c|c|c|c|}
\hline \multirow{3}{*}{$\begin{array}{l}\text { Resolving } \\
\text { power in } \\
\text { lines per } \mathrm{mm}\end{array}$} & \multicolumn{14}{|c|}{$\begin{array}{c}\text { Distribution of maximal values of the resolving power for the } 30 \mathrm{f} / 4 \text { lenses of foreign } \\
\text { manufacture }\end{array}$} \\
\hline & \multicolumn{7}{|c|}{$\begin{array}{c}\text { Tangential. } \\
\text { Angular distance from axis. }\end{array}$} & \multicolumn{7}{|c|}{$\begin{array}{c}\text { Radial. } \\
\text { Angular distance from axis. }\end{array}$} \\
\hline & $0^{\circ}$ & $5^{\circ}$ & $10^{\circ}$ & $15^{\circ}$ & $20^{\circ}$ & $25^{\circ}$ & $30^{\circ}$ & $0^{\circ}$ & $5^{\circ}$ & $10^{\circ}$ & $15^{\circ}$ & $20^{\circ}$ & $25^{\circ}$ & $30^{\circ}$ \\
\hline
\end{tabular}

(a) Image plane $0.5 \mathrm{~mm}$ farther from lens than image plane of best average definition

\begin{tabular}{|c|c|c|c|c|c|c|c|c|c|c|c|c|c|c|}
\hline $\begin{array}{l}2 \\
0\end{array}$ & 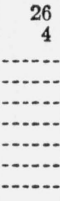 & 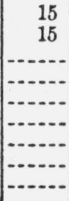 & \begin{tabular}{r}
2 \\
9 \\
11 \\
6 \\
2 \\
\hdashline..- \\
\hdashline..- \\
.-
\end{tabular} & $\begin{array}{r}-1 \\
7 \\
6 \\
11 \\
5\end{array}$ & $\begin{array}{r}1 \\
2 \\
10 \\
2 \\
15\end{array}$ & $\begin{array}{r}1 \\
11 \\
4 \\
12 \\
2\end{array}$ & $\begin{array}{r}-10 \\
8 \\
8 \\
10 \\
3\end{array}$ & $\begin{array}{r}24 \\
6 \\
\hdashline \\
\\
\hdashline \\
\\
\hdashline\end{array}$ & 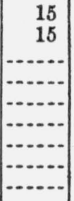 & \begin{tabular}{r}
1 \\
10 \\
10 \\
3 \\
6 \\
\hdashline.. \\
\hdashline... \\
\end{tabular} & 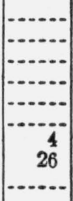 & $\begin{array}{r}0 . \\
\hdashline 1 \\
\hdashline 0 \\
\hdashline 0\end{array}$ & $\begin{array}{r}18 \\
\\
\\
\end{array}$ & $\begin{array}{r}4 \\
2 \\
3 \\
7 \\
11 \\
1 \\
2\end{array}$ \\
\hline
\end{tabular}


TABLE 6.-Occurrence tables showing the distribution of maximal values of the resolving power for three image planes-Continued

\begin{tabular}{|c|c|c|c|c|c|c|c|c|c|c|c|c|c|c|}
\hline \multirow{3}{*}{$\begin{array}{c}\text { Resolving } \\
\text { power in } \\
\text { lines per } \mathrm{mm}\end{array}$} & \multicolumn{14}{|c|}{$\begin{array}{c}\text { Distribution of maximal values of the resolving power for the } 30 \mathrm{f} / 4 \text { lenses of foreign } \\
\text { manufacture }\end{array}$} \\
\hline & \multicolumn{7}{|c|}{$\begin{array}{l}\text { Tangential. } \\
\text { Angular distance from axis. }\end{array}$} & \multicolumn{7}{|c|}{$\begin{array}{l}\text { Radial. } \\
\text { Angular distance from axis. }\end{array}$} \\
\hline & $0^{\circ}$ & $5^{\circ}$ & $10^{\circ}$ & $15^{\circ}$ & $20^{\circ}$ & $25^{\circ}$ & $30^{\circ}$ & $0^{\circ}$ & $5^{\circ}$ & $10^{\circ}$ & $15^{\circ}$ & $20^{\circ}$ & $25^{\circ}$ & $30^{\circ}$ \\
\hline
\end{tabular}

(b) Image plane of best average definition

\begin{tabular}{|c|c|c|c|c|c|c|c|c|c|c|c|c|c|c|}
\hline $\begin{array}{l}56 \\
40 \\
28 \\
20 \\
14 \\
10 \\
70 \\
5 \\
3.5\end{array}$ & \begin{tabular}{r}
1 \\
12 \\
9 \\
6 \\
2 \\
\hdashline-9 \\
-0 \\
\end{tabular} & \begin{tabular}{r}
4 \\
17 \\
8 \\
1 \\
\hdashline- \\
\\
\hdashline \\
\\
\end{tabular} & 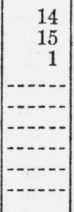 & $\begin{array}{r}8 \\
10 \\
5 \\
4 \\
3 \\
\hdashline- \\
\hdashline\end{array}$ & 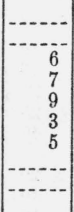 & $\begin{array}{r}- \\
12 \\
10 \\
2 \\
2\end{array}$ & $\begin{array}{r}-1 \\
3 \\
10 \\
14 \\
1 \\
1 \\
-1\end{array}$ & 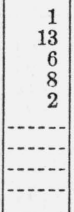 & 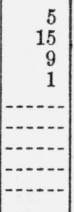 & 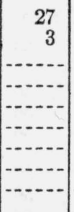 & $\begin{array}{r}1 \\
3 \\
2 \\
4 \\
19 \\
1 \\
\hdashline-\end{array}$ & 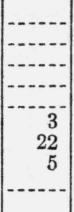 & 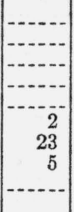 & $\begin{array}{r}2 \\
19 \\
5 \\
2 \\
-1 \\
1 \\
\end{array}$ \\
\hline
\end{tabular}

(c) Image plane $0.5 \mathrm{~m} \cdot \mathrm{n}$ nearer to the lens than the image plane of best average definition

\begin{tabular}{|c|c|c|c|c|c|c|c|c|c|c|c|c|c|c|}
\hline $\begin{array}{l}56 \\
40 \\
28 \\
20 \\
14 \\
10 \\
70 \\
5 \\
3.5\end{array}$ & \begin{tabular}{r}
$-\cdots$ \\
\hdashline-1 \\
5 \\
18 \\
6 \\
$-\cdots$
\end{tabular} & $\begin{array}{r}1 \\
5 \\
6 \\
10 \\
7 \\
1\end{array}$ & $\begin{array}{r}3 \\
15 \\
7 \\
2 \\
3 \\
\hdashline- \\
\hdashline\end{array}$ & 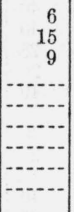 & $\begin{array}{r}8 \\
9 \\
12 \\
1 \\
\hdashline-1 \\
\hdashline\end{array}$ & 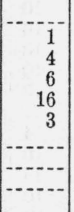 & $\begin{array}{r}1 \\
7 \\
16 \\
5 \\
1 \\
\hdashline \\
\hdashline\end{array}$ & $\begin{array}{r}-r \\
25 \\
3 \\
\hdashline\end{array}$ & $\begin{array}{r}-\ldots 1 \\
\cdots \\
14 \\
\cdots \\
\cdots\end{array}$ & $\begin{array}{r}1 \\
1 \\
14 \\
11 \\
2 \\
1 \\
-1 \\
-1 \\
\end{array}$ & 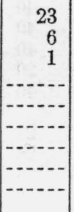 & $\begin{array}{r}2 \\
6 \\
3 \\
14 \\
5 \\
\hdashline \\
\hdashline\end{array}$ & $\begin{array}{r}1 \\
4 \\
6 \\
3 \\
13 \\
3 \\
0\end{array}$ & 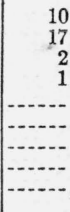 \\
\hline
\end{tabular}

TABLE 7.-Average resolving powers for the $30 \mathrm{f} / 4$ lenses of foreign manufacture

\begin{tabular}{|c|c|c|c|c|c|c|c|c|c|c|c|c|c|c|}
\hline \multirow[t]{2}{*}{ Image plane } & \multicolumn{7}{|c|}{$\begin{array}{l}\text { Tangential resolving power in lines per } \\
\text { millimeter. } \\
\text { Angular distance from axis. }\end{array}$} & \multicolumn{7}{|c|}{$\begin{array}{l}\text { Radial resolving power in lines per millimeter. } \\
\text { Angular distance from axis. }\end{array}$} \\
\hline & $0^{\circ}$ & $5^{\circ}$ & $10^{\circ}$ & $15^{\circ}$ & $20^{\circ}$ & $25^{\circ}$ & $30^{\circ}$ & $0^{\circ}$ & $5^{\circ}$ & $10^{\circ}$ & $15^{\circ}$ & $20^{\circ}$ & $25^{\circ}$ & $30^{\circ}$ \\
\hline$(a) \ldots$ & 54 & 48 & 22 & 9 & 8 & 8 & 10 & 53 & 48 & 21 & 5 & 5 & 4 & 17 \\
\hline$(\theta) \ldots$ & 31 & 38 & 47 & 26 & 17 & 12 & 13 & 31 & 38 & 54 & 14 & 7 & 7 & 36 \\
\hline (c) $\ldots$ & 7 & 12 & 25 & 40 & 28 & 18 & 15 & 7 & 9 & 25 & 52 & 18 & 16 & 44 \\
\hline
\end{tabular}

(a) Image plane $0.5 \mathrm{~mm}$ farther from the lens thanjimage plane of best average definition.

(b) Image plane of best average deflnition.

(c) Image plane $0.5 \mathrm{~mm}$ nearer to the lens than the image plane of best average definition.

Table 8 lists the resolving power at $5^{\circ}$ intervals in the image plane of best average definition for $20 \mathrm{f} / 6.8$ lenses of domestic manufacture. Occurrence tables that give studies of the values of the resolving powers in image planes at different distances from the lens are shown in table 9. Values for an image plane $1.0 \mathrm{~mm}$ farther from the lens than the plane of best average definition have been considered admissible for the $f / 6.8$ lenses, because their depth of focus is greater than that of the $f / 4$ lenses. The limited range covered by the test negatives that were used in this study precluded the showing of analogous data for an image plane $1.0 \mathrm{~mm}$ nearer to the lens than 
the plane of best average definition. It is evident, however, that most of the values for this condition would be lower than the values reported at $0.5 \mathrm{~mm}$ nearer to the lens than the plane of best average definition. This has been corroborated to some extent by inspection of negatives for two similar lenses where the range traversed by the

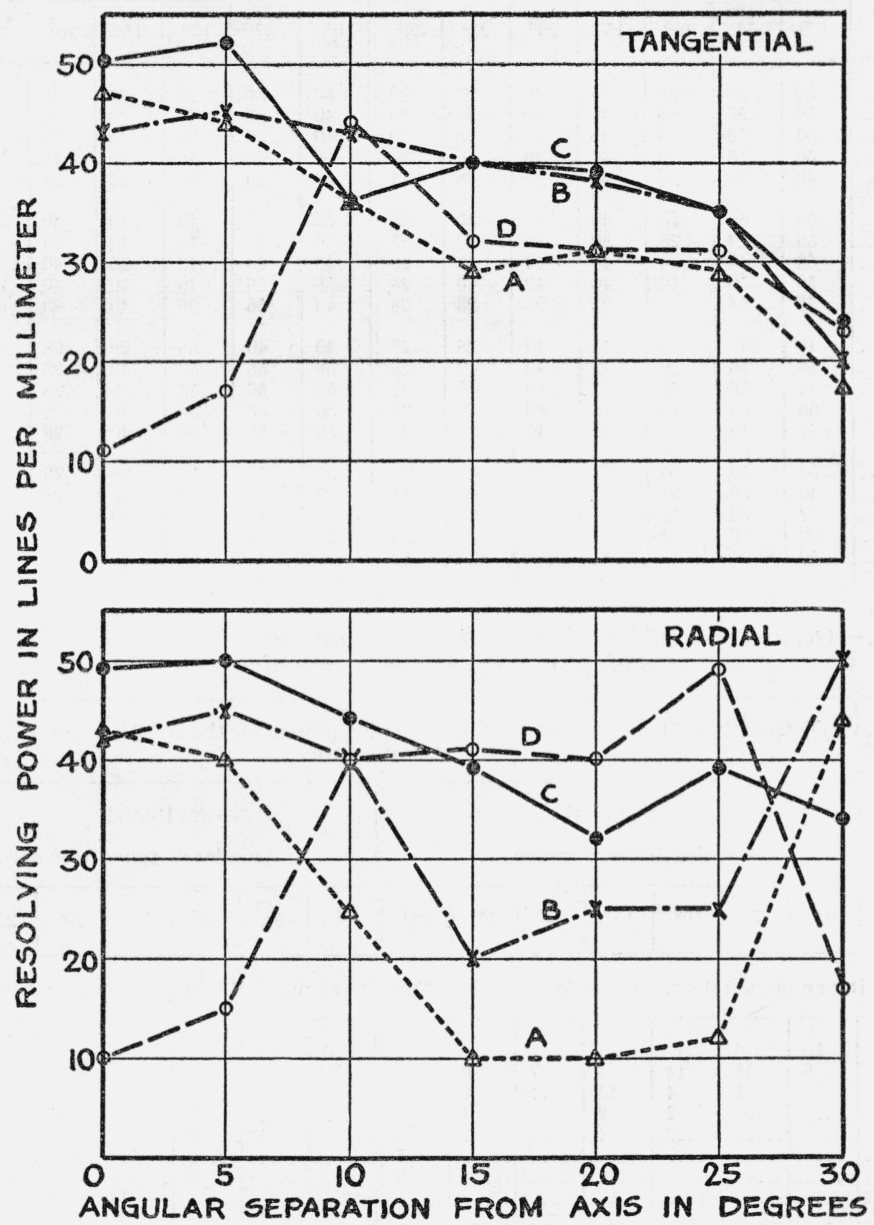

FIGURE 4.-Graphs showing the tangential and radial resolving powers for $20 \mathrm{f} / 6.8$ lenses of domestic manufacture.

$A$, image plane $1.0 \mathrm{~mm}$ farther from the lens than the plane of best average definition. $B$, image plane 0.5 $\mathrm{mm}$ farther from the lens than the plane of best average definition. $C$, image plane of best average definition. $D$, image plane $0.5 \mathrm{~mm}$ nearer to the lens than the plane of best average definition.

test plate permitted a study at $1.0 \mathrm{~mm}$ nearer to the lens. A compilation of the average resolving power for each angular separation from the axis of the lens and for each image plane is given in table 10. Curves giving a graphical picture of the resolving powers in the four image planes are shown in figure 4. 
742 Journal of Research of the National Bureau of Standards

Vol. $2 \%$

TABLE 8. -Resolving power of $20 \mathrm{f} / 6.8$ lenses of domestic manufacture in the image plane of best average resolving power

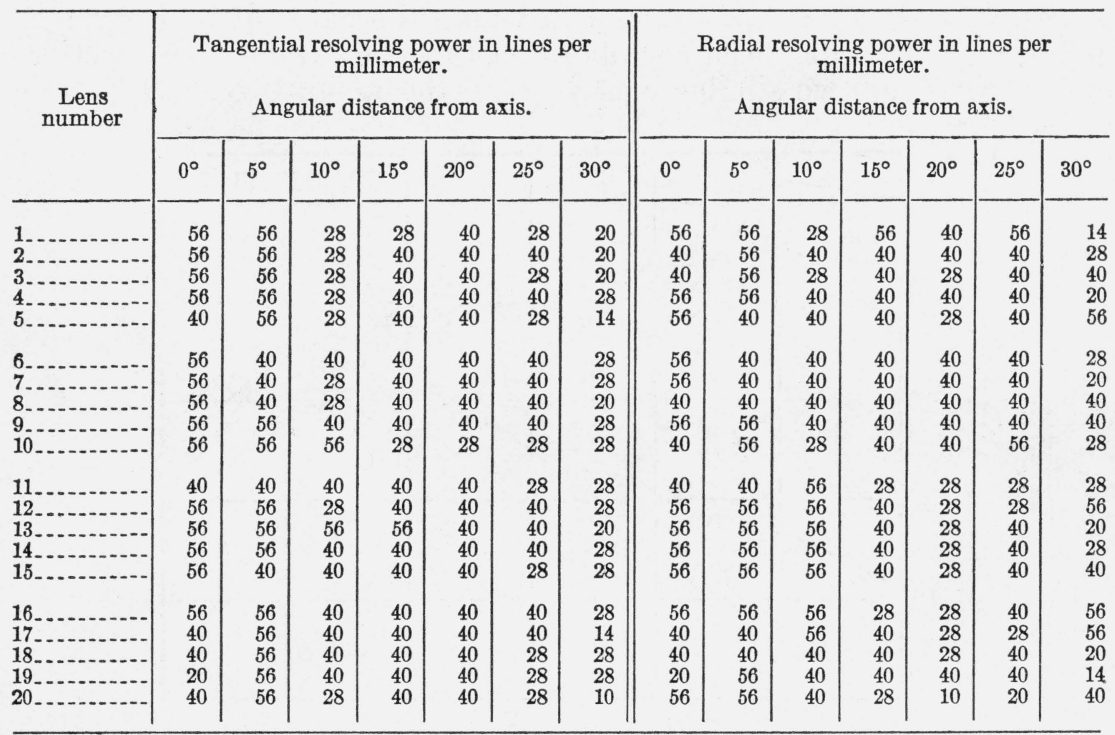

TABLE 9.-Occurrence tables showing the distribution of maximal values of the resolving power for four image planes

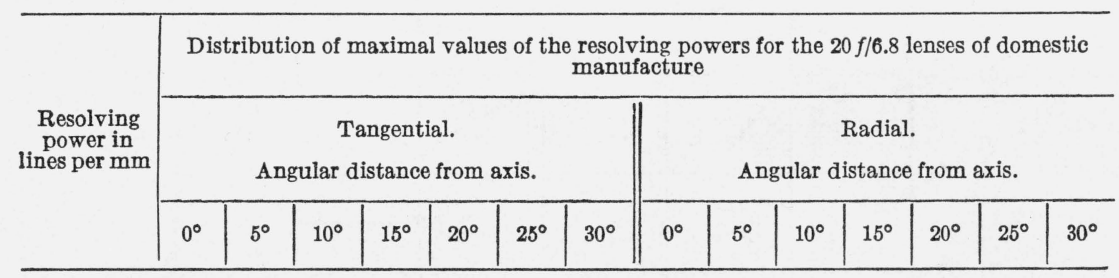

(a) Image plane $1.0 \mathrm{~mm}$ farther from the lens than image plane of best average definition

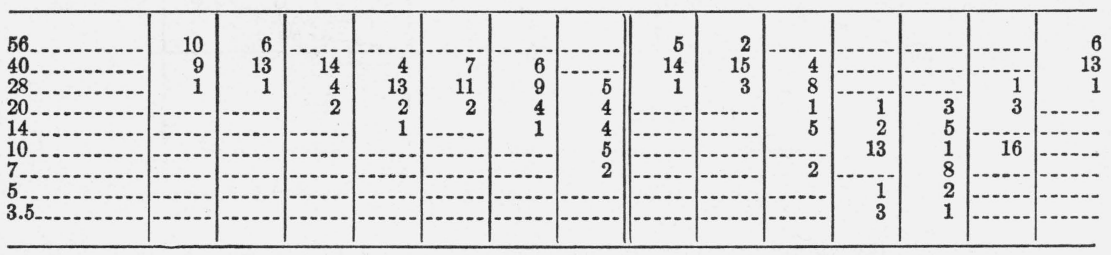

(b) Image plane $0.5 \mathrm{~mm}$ farther from the lens than image plane of best average definition

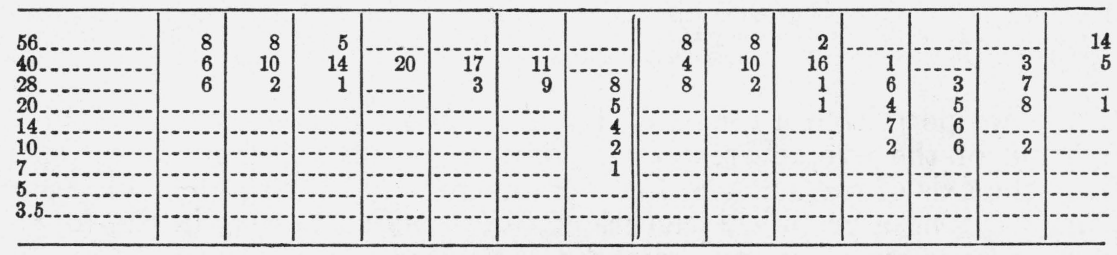


TABLE 9.-Occurrence tables showing the distribution of maximal values of the resolving power for four image planes-Continued

\begin{tabular}{|c|c|c|c|c|c|c|c|c|c|c|c|c|c|c|}
\hline \multirow{3}{*}{$\begin{array}{c}\text { Resolving } \\
\text { power in } \\
\text { lines per } \mathrm{mm}\end{array}$} & \multicolumn{14}{|c|}{$\begin{array}{c}\text { Distribution of maximal values of the resolving powers for the } 20 \mathrm{f} / 6.8 \text { lenses of domestic } \\
\text { manufacture }\end{array}$} \\
\hline & \multicolumn{7}{|c|}{$\begin{array}{l}\text { Tangential. } \\
\text { Angular distance from axis. }\end{array}$} & \multicolumn{7}{|c|}{$\begin{array}{l}\text { Radial. } \\
\text { Angular distance from axis. }\end{array}$} \\
\hline & $0^{\circ}$ & $5^{\circ}$ & $10^{\circ}$ & $15^{\circ}$ & $20^{\circ}$ & $25^{\circ}$ & $30^{\circ}$ & $0^{\circ}$ & $5^{\circ}$ & $10^{\circ}$ & $15^{\circ}$ & $20^{\circ}$ & $25^{\circ}$ & $30^{\circ}$ \\
\hline
\end{tabular}

(c) Image plane of best average definition

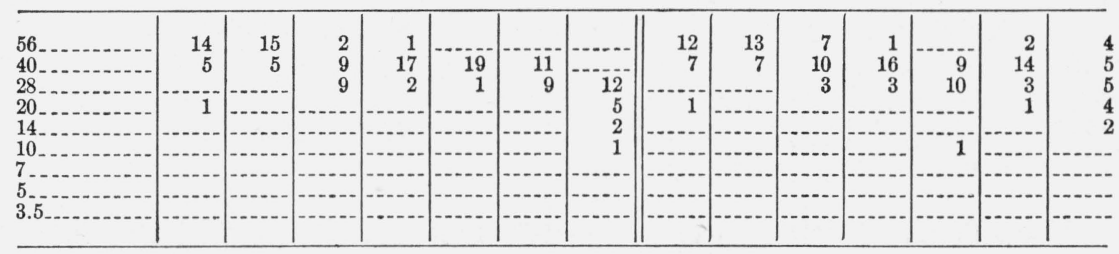

(d) Image plane $0.5 \mathrm{~mm}$ nearer to the lens than the image plane of best average definition

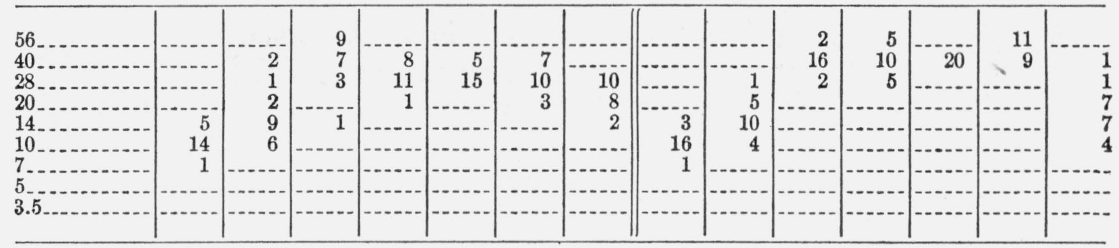

TABLE 10.-Average resolving power for the $20 \mathrm{f} / 6.8$ lenses of domestic manufacture

\begin{tabular}{|c|c|c|c|c|c|c|c|c|c|c|c|c|c|c|}
\hline \multirow[t]{2}{*}{ Image plane } & \multicolumn{7}{|c|}{$\begin{array}{c}\text { Tangential resolving power in lines per } \\
\text { millimeter } \\
\text { Angular distance from axis }\end{array}$} & \multicolumn{7}{|c|}{$\begin{array}{l}\text { Radial resolving power in lines per milli- } \\
\text { meter } \\
\text { Angular distance from axis }\end{array}$} \\
\hline & $0^{\circ}$ & $5^{\circ}$ & $10^{\circ}$ & $15^{\circ}$ & $20^{\circ}$ & $25^{\circ}$ & $30^{\circ}$ & $0^{\circ}$ & $5^{\circ}$ & $10^{\circ}$ & $15^{\circ}$ & $20^{\circ}$ & $25^{\circ}$ & $30^{\circ}$ \\
\hline (a)... & 47 & 44 & 36 & 29 & 31 & 29 & 17 & 43 & 40 & 24 & 10 & 10 & 12 & 44 \\
\hline (b) $\ldots$ & 43 & 45 & 43 & 40 & 38 & 35 & 20 & 42 & 45 & 40 & 20 & 25 & 25 & 50 \\
\hline (c) $\ldots$ & 50 & 52 & 36 & 40 & 39 & 35 & 24 & 49 & 50 & 44 & 39 & 32 & 39 & 34 \\
\hline (d) $\ldots$ & 11 & 17 & 44 & 32 & 31 & 31 & 23 & 10 & 15 & 40 & 41 & 40 & 49 & 17 \\
\hline
\end{tabular}

(a) Image plane $1.0 \mathrm{~mm}$ farther from the lens than the image plane of best average definition.

(b) Image plane $0.5 \mathrm{~mm}$ farther from the lens than the image plane of best average definition.

(c) Image plane of best average definition.

(d) Image plane $0.5 \mathrm{~mm}$ nearer to the lens than the image plane of best average definition.

Inspection of the values of the resolving powers, shown in table 10 , indicates that they are generally higher than the corresponding values for the $f / 4$ lenses. As a result, it is possible to secure good imagery over a fairly wide range. The selection of the image plane of best definition is here done with the aid of contours drawn on the test negative. Each image on the test negative is labeled with the lower of the two maximum values of the resolving power present therein, that is, tangential and radial. Lines are then drawn on the negative to enclose the regions of equal resolving power across the test negative in a manner closely analogous to the contour lines drawn on a map to show the regions of equal elevation. A row is 
then selected which gives the best average definition across the entire negative. Consideration of figure 4 shows that this method has given fairly consistent results. It is clear that the curve showing the resolving power for the image plane adjudged to yield best average definition is more often above than below the curves for the other image planes reported. For tangential definition it is below only at $10^{\circ}$. For radial definition the case is not quite so clear in this respect, but the curve is more uniform than the others. The definition in the selected image plane is definitely superior to the definition in the image planes $1.0 \mathrm{~mm}$ and $0.5 \mathrm{~mm}$ farther from the lens except at $30^{\circ}$. In four of seven instances, the selected image plane for radial imagery gives better resolution than the image plane $0.5 \mathrm{~mm}$ nearer to the lens, and is markedly superior in three of these four instances. For the three instances where the resolving power in the selected image plane is lower than that in the image plane $0.5 \mathrm{~mm}$ nearer to the lens, the disparity is small.

\section{DISTORTION FOR TYPICAL AIRPLANE-CAMERA LENSES}

1 prime requirement of a lens that is to be used in producing riegatives suitable for measurement in air-map work is low distortion. Distortion, as herein used, is the linear displacement of an imaged point from the point where it would have been imaged if the lens were perfectly orthoscopic. This displacement is measured in the image plane along a radius drawn from the intersection point of lens axis and image plane. To obtain the value of the distortion at a given angular separation from the axis, it is necessary to measure the distance from the point where the axis cuts the image plane to the image of a point which, in the object space, is at the given angular separation from the axis. Let this distance be $L$. Then, $L-f \tan \theta=D$, yields the distortion, $D$, where $f$ is the equivalent focal length corresponding to the image plane in which the measurements are made, and $\theta$ is the given angular separation from the axis. If $D$ is positive, the displacement is away from the center of the field.

This section is devoted to a review of the values of the distortion of some of the lenses whose resolving powers are surveyed in section III. Comparison of the values herein reported with those contained in a publication ${ }^{5}$ by $\mathrm{A}$. $\mathrm{H}$. Bennett shows that marked reduction of distortion has been made in the past 10 years by the lens manufacturers. In these tabulations of distortion, no attempt is made to strike an average. To do so would tend to confuse matters and to imply that lower values of the distortion than those herein reported are readily possible. If comparisons of the distortions of different lenses are made, the differences in distortion are likely to be as great between two lenses of the same make as would be the case between two lenses of different makes.

No tabulations are given to show the variation of distortion in image planes at differing distances from the lens. The range through which the test plate travels in recording usable imagery is so small in comparison to the focal length that changes in distortion with distance from the lens for the region studied are negligible.

\footnotetext{
o J. Opt. Soc. Am. and Rev. Sci. Instr. 14, 235 (1927).
} 
The present goal is that distortion should not exceed $\pm 0.10 \mathrm{~mm}$ at any point in the field. This value is to be regarded as the upper limit of distortion when the computations of distortion are based upon the paraxial or equivalent focal length. When the lens, mounted in an airplane camera in the position where it is to be used in practice, is tested, it is possible to obtain lower values of the distortion by referring it to the calibrated focal length. This calibrated focal length is obtained by modifying the equivalent focal length in such a manner that the errors arising from distortion are minimized and distributed approximately uniformly over the entire field. Hence, in precision cameras, the requirement is that the distortion must not exceed $\pm 0.025 \mathrm{~mm} .{ }^{6}$ In the tables that follow, the values of the distortion are based upon the equivalent focal length, and the performance of the lens is to be judged with reference to the $\pm 0.10 \mathrm{~mm}$ requirement.

Table 11 gives the distortion at $5^{\circ}$ intervals from $5^{\circ}$ to $30^{\circ}$ for the $10 \mathrm{f} / 4$ domestic lenses whose resolving powers are shown in table 2 . Inspection of this table shows that none of these 10 lenses has distortion in excess of $\pm 0.10 \mathrm{~mm}$ at $30^{\circ}$, and all are well within this limit for the lesser angles. The second column gives the values of the equivalent focal lengths which were used in determining the distortion.

Table 12 surveys the distortion at $5^{\circ}$ intervals from $5^{\circ}$ to $30^{\circ}$ for $25 \mathrm{f} / 4$ lenses of foreign manufacture; these are some of the same lenses whose resolving powers are reported in table 5 . The equivalent focal length for each lens is given in column 2. Examination of this table shows that all 25 lenses have distortion within the limit of $\pm 0.10 \mathrm{~mm}$ for all angular separations from the axis out to and including $20^{\circ}$. At $25^{\circ}$, lens 11 is outside the requirement with a distortion of $-0.14 \mathrm{~mm}$, and at $30^{\circ}, 14$ of the 25 lenses show distortion in excess of $\pm 0.10 \mathrm{~mm}$.

Table 13 shows the distortion at $5^{\circ}$ intervals from $5^{\circ}$ to $30^{\circ}$ for 15 of the $20 \mathrm{f} / 6.8$ lenses of domestic manufacture whose resolving powers are reported in table 8 . The second column gives the equivalent focal length for each lens. All of the values of the distortion for each angle are well within the requirements of $\pm 0.10 \mathrm{~mm}$.

TABLE 11.-Distortion of $10 \mathrm{f} / 4$ lenses of domestic manufacture

\begin{tabular}{|c|c|c|c|c|c|c|c|}
\hline \multirow{2}{*}{ Lens number } & \multirow{2}{*}{ E. F. L. } & \multicolumn{6}{|c|}{ Angular distance from the axis } \\
\hline & & $5^{\circ}$ & $10^{\circ}$ & $15^{\circ}$ & $20^{\circ}$ & $25^{\circ}$ & $30^{\circ}$ \\
\hline $\begin{array}{l}1 \\
2 \\
3 \\
4 \\
5\end{array}$ & $\begin{array}{l}m m \\
210.02 \\
211.06 \\
210.52 \\
211.33 \\
210.09\end{array}$ & $\begin{array}{r}m m \\
0.00 \\
.00 \\
.00 \\
.00 \\
.00\end{array}$ & $\begin{array}{r}m m \\
-0.01 \\
.00 \\
-.01 \\
.00 \\
.00\end{array}$ & $\begin{array}{r}m m \\
-0.01 \\
.00 \\
-.02 \\
.00 \\
+.01\end{array}$ & $\begin{array}{l}m m \\
-0.02 \\
.00 \\
-.02 \\
+.02 \\
+.02\end{array}$ & $\begin{array}{l}m m \\
-0.01 \\
+.02 \\
+.02 \\
+.03 \\
+.04\end{array}$ & $\begin{array}{r}m m \\
0.00 \\
+.07 \\
+.01 \\
+.02 \\
+.08\end{array}$ \\
\hline $9^{6}$ & $\begin{array}{l}210.13 \\
210.77 \\
210.29 \\
210.29 \\
211.15\end{array}$ & $\begin{array}{l}.00 \\
.00 \\
.00 \\
.00 \\
.00\end{array}$ & $\begin{array}{l}.00 \\
.00 \\
.00 \\
.00 \\
.00\end{array}$ & $\begin{array}{r}+.01 \\
.00 \\
-.01 \\
+.00 \\
+.01\end{array}$ & $\begin{array}{r}+.02 \\
.00 \\
-.02 \\
+.00 \\
+.02\end{array}$ & $\begin{array}{l}+.05 \\
+.01 \\
+.01 \\
+.01 \\
+.03\end{array}$ & $\begin{array}{l}+.10 \\
+.02 \\
+.02 \\
+.02 \\
+.06\end{array}$ \\
\hline
\end{tabular}

o J. Research NBS 22, 209 (1939) RP1177. 
TABLE 12.-Distortion of $25 \mathrm{f} / 4$ lenses of foreign manufacture

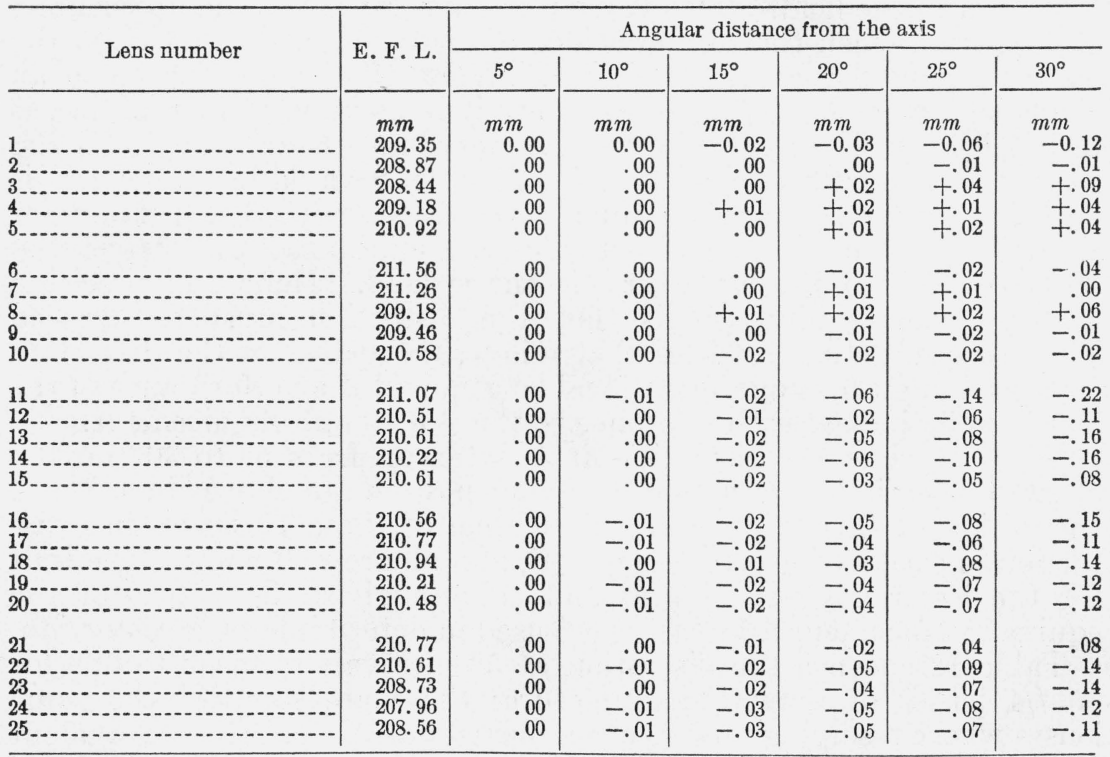

TABLE 13.-Distortion of $15 \mathrm{f} / 6.8$ lenses of domestic manufacture

\begin{tabular}{|c|c|c|c|c|c|c|c|}
\hline \multirow{2}{*}{ Lens number } & \multirow{2}{*}{ E. F. L. } & \multicolumn{6}{|c|}{ Angular distance from the axis } \\
\hline & & $5^{\circ}$ & $10^{\circ}$ & $15^{\circ}$ & $20^{\circ}$ & $25^{\circ}$ & $30^{\circ}$ \\
\hline 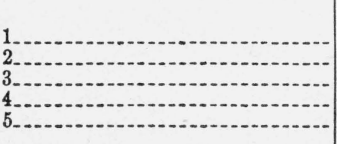 & $\begin{array}{l}m m \\
208.70 \\
209.33 \\
210.00 \\
210.05 \\
209.98\end{array}$ & $\begin{array}{r}m m \\
0.00 \\
.00 \\
.00 \\
.00 \\
.00\end{array}$ & $\begin{array}{r}m m \\
0.00 \\
.00 \\
.00 \\
.00 \\
.00\end{array}$ & $\begin{array}{r}m m \\
-0.01 \\
.00 \\
.00 \\
.00 \\
.00\end{array}$ & $\begin{array}{l}m m \\
-0.02 \\
+.01 \\
-.01 \\
.00 \\
-.01\end{array}$ & $\begin{array}{l}m m \\
-0.03 \\
+.02 \\
-.01 \\
+.02 \\
-.02\end{array}$ & $\begin{array}{r}m m \\
-0.04 \\
+.06 \\
.00 \\
+.06 \\
.00\end{array}$ \\
\hline 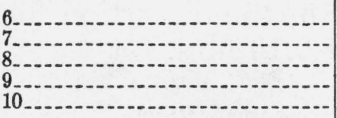 & $\begin{array}{l}209.73 \\
209.69 \\
209.73 \\
209.77 \\
209.76\end{array}$ & $\begin{array}{r}.00 \\
.00 \\
.00 \\
.00 \\
.00\end{array}$ & $\begin{array}{l}.00 \\
.00 \\
.00 \\
.00 \\
.00\end{array}$ & $\begin{array}{r}.00 \\
.00 \\
.00 \\
.00 \\
-.01\end{array}$ & $\begin{array}{r}-.01 \\
-.01 \\
.00 \\
-.01 \\
-.01\end{array}$ & $\begin{array}{r}-.01 \\
-.02 \\
.00 \\
-.01 \\
+.01\end{array}$ & $\begin{array}{r}+.01 \\
.00 \\
+.04 \\
+.02 \\
+.03\end{array}$ \\
\hline $\begin{array}{l}11 \\
12 \\
13 \\
15\end{array}$ & $\begin{array}{l}209.77 \\
209.56 \\
209.66 \\
209.75 \\
210.01\end{array}$ & $\begin{array}{l}.00 \\
.00 \\
.00 \\
.00 \\
.00\end{array}$ & $\begin{array}{l}.00 \\
.00 \\
.00 \\
.00 \\
.00\end{array}$ & $\begin{array}{r}-.01 \\
-.01 \\
-.01 \\
.00 \\
.00\end{array}$ & $\begin{array}{r}-.02 \\
-.01 \\
-.01 \\
.00 \\
.00\end{array}$ & $\begin{array}{r}-.03 \\
.00 \\
-.01 \\
+.01 \\
+.02\end{array}$ & $\begin{array}{l}-.02 \\
+.05 \\
+.01 \\
+.03 \\
+.05\end{array}$ \\
\hline
\end{tabular}

\section{CONCLUSION}

Only lenses tested since January 1937 have been considered in this study. Each group represents a random sample of the lenses of a given make that were submitted for test. The present requirements for an airplane-camera objective having a focal length of $210 \mathrm{~mm}$ and covering a 7 - by 9 -inch film are that the distortion referred to the paraxial or equivalent focal length shall not exceed $\pm 0.10 \mathrm{~mm}$ at $30^{\circ}$ from the axis, and that the resolving power in any orientation shall not fall below seven lines to the millimeter throughout the region from $0^{\circ}$ to $30^{\circ}$ as measured from the axis of the lens. On the basis of the tables contained in this paper, it is clear that the domestic lenses whose test records here appear satisfactorily meet the requirements for use on air-mapping projects.

Washington, November 18, 1938. 